Article

\title{
Greenery System for Cooling Down Outdoor Spaces: Results of an Experimental Study
}

\author{
Marta Chàfer ${ }^{1,2}(\mathbb{D}$, Anna Laura Pisello $2,3(\mathbb{0}$, Cristina Piselli $2,3(\mathbb{B}$ and Luisa F. Cabeza $1, * \mathbb{C}$ \\ 1 GREiA Research Group, University of Lleida, 25001 Lleida, Spain; marta.chafer@udl.cat \\ 2 CIRIAF-Interuniversity Research Centre, University of Perugia, 06125 Perugia, Italy; \\ anna.pisello@unipg.it (A.L.P.); cristina.piselli@unipg.it (C.P.) \\ 3 Department of Engineering, University of Perugia, 06125 Perugia, Italy \\ * Correspondence: luisaf.cabeza@udl.cat; Tel.: +34-97-300-3576
}

Received: 24 May 2020; Accepted: 17 July 2020; Published: 22 July 2020

\begin{abstract}
Urban green infrastructure (UGI) and nature-based solutions (NBS) are increasingly recognized as strategies to address urban sustainability challenges. These solutions are attracting key scientific and marketing attention thanks to their capability to improve indoor and outdoor thermal comfort and environmental quality of spaces. In urban areas, where most of the population worldwide lives, indoor-outdoor environmental quality is compromised by local and temporary overheating phenomena, air pollution concentration, and impervious surfaces minimizing urban space resilience to climate change related hazards. In this view, the proposed study concerns the analysis of a greenery system for enhancing outdoor thermal conditions and local warming mitigation for pedestrians for the continental Mediterranean climate. The system has the purpose of designing an outdoor "alive" shading system to be applied in open public spaces, with producing physical and societal benefits. The experimental results showed that the implementation of the greenery, characterized by lower surface temperatures and evapotranspiration compared to a simple pergola system, allows the reduction of outdoor air temperature under the shading system and, thus, higher relative humidity in summer. Specifically, the hygrothermal cooling and the additional shading thanks to the presence of greenery provide local air temperature reduction up to $5^{\circ} \mathrm{C}$ at pedestrian level.
\end{abstract}

Keywords: greenery; outdoor microclimate; cooling effect; biophilic cities; thermal environment

\section{Introduction}

Nowadays, a topic with increasing relevance is how an outdoor space affects physical, physiological, and psychological well-being. The achievement of comfortable outdoor spaces and microclimates in urban environment is, indeed, fundamental for the exploitation of social activities, often enhanced by means of a better connection to nature through sunny and/or green spaces [1].

Architects and designers were inspired by nature since long before the term biomimetics (or bio-inspired architecture) was introduced.

The concept of biomimetic design from nature in the built environment can be understood in various terms, among others biomimicry, biomimetic, bionic, bio design, biophilia, and bio derivation. Biomimetics is a rapidly growing discipline in engineering and an emerging design field in architecture [2]. Systems found in nature offer a large database of strategies and mechanisms that can be implemented in biomimetic designs [3,4]. Moreover, it is believed that the incorporation of a thorough understanding of biology and ecology into architectural design will be significant in the creation of a built environment that contributes to the health of human communities, while increasing positive integration with natural carbon cycles [5]. 
In this context, nature-based solutions (NBS) or urban green infrastructure (UGI) emerged as a concept to operationalize an ecosystem services approach [6,7] and to foster the functioning of ecosystems as essential backbones to climate change mitigation and adaptation [8,9]. The benefits of UGI were widely studied in recent years $[10,11]$. In fact, green infrastructures can help in achieving temperature reductions in urban areas and influencing the mitigation of urban heat risks, while delivering diverse additional benefits such as pollution reduction and biodiversity habitat [12-14]. Concerning street canyons, vegetation can create an efficient urban pollutant filter that improves the air quality at street-level in dense urban areas [15]. Furthermore, plants have the capability of transforming the global solar radiation that reaches their surfaces into biomass, oxygen, air humidity, etc. [16]. In particular, urban trees are widely promoted as a solution to cool the urban environment thanks to shading and evaporative cooling provided by tree canopies $[17,18]$, in addition to other multiple benefits such as flood management, wildlife habitat and natural pathway creation, neighborhood beautification, cost-effectiveness, etc. [19]. Regarding the building scale, in addition to their aesthetical and health benefits, green infrastructure such as green walls and green roof have significant thermal effects on indoor building environments [20-22] and urban heat island (UHI) effect [23,24].

Another important aspect is that outdoor green spaces promote physical activity and public health $[25,26]$. The World Health Organization [27] offered in their report a review of the existing evidence on the health effects of green spaces in urban areas. Another study [28] found evidence-based design of greenery solutions to be beneficial for mental health, especially to those diagnosed with mental disorders. The opportunity of contact with nature or the use of more biodiverse environments certainly represent an important aspect of healthy ageing and dementia-friendly environments.

In this context, biophilic spaces (i.e., those that learn from nature and emulate natural systems) must be considered for the development of cities [29]. In fact, a "biophilic city", as Beatley and Newman [30] deeply studied, is a city in which residents are actively involved in experiencing nature. Biophilic design holds that good design, at the building, site, city, and regional scale, must include nature and natural elements. Moreover, biophilic urbanism can help to protect or strengthen favorable climate and micro-climate conditions in cities. It can also complement urban greening efforts to enable a holistic approach, which is conducive to comprehensive, intentional, and strategic urban greening [31,32], and also to address climate change issues in rapidly growing economies [33,34].

Regarding the effect of greenery in the outdoors, different studies were found in the literature. Piselli et al. [35] affirmed that pedestrians are in favor of additional green areas and this increase of vegetation, combined to other solutions for sustainable landscape change, showed a significant impact in summer overheating mitigation and urban resilience to anthropogenic climate change. Also, Morakinyo et al. [36] studied the effect of vertical greenery on thermal comfort and air cooling via its effect on building facade surface energy fluxes and air temperature in Hong Kong. They found that $30-50 \%$ of facades in the high-density urban setting of Hong Kong should be greened to potentially cause a $1{ }^{\circ} \mathrm{C}$ reduction in both daytime and night time temperatures. Jusuf et al. [37], conducted a mobile survey to explore both the severity of UHI effect and cooling impacts of green areas in Singapore. The results indicated a strong correlation between the decrease of temperature and the appearance of large green areas in the city, and a maximum temperature difference of about $4{ }^{\circ} \mathrm{C}$ was observed.

Within this background, it appears crucial to consider greenery as an important element in any contemporary urban planning. However, green systems definitely are not new creations. Vegetation has existed on earth since the beginning of time. Outdoor shading structures, such as trellises and pergolas, can be used for providing shade and/or to control air movement [38]. For example, pergolas developed out of the Etruscan practice of training vines high on trees; their functionality and simplicity made them a staple in history and will most likely continue to be a popular feature.

Therefore, there is an opportunity to experimentally exploit the influence of greenery for cooling down air temperatures, which provides benefits not only in terms of outdoor thermal comfort, but also indoors. In this study, two pergolas, structurally the same, but differing in the presence of greenery, were analyzed in order to assess the thermal effect of the greenery on outdoor air temperatures. 
This case study took place in Lleida, Spain under a continental Mediterranean climate. Results showed an encouraging "cooling effect" with the implementation of greenery. Finally, the special aim is to point out the importance and necessity of increasing vegetation within cities, both at the local level for the improvement of microclimate and at a wider level for the mitigation of climate change.

\section{Materials and Methods}

\subsection{Experimental Set-up: The Green Pergola}

This study was carried out in the experimental set-up in Puigverd de Lleida (Spain), where 22 houselike cubicles have been tested with active and passive building heating and cooling technologies during the last decade [39]. The climate in Lleida is a continental Mediterranean climate that is classified as Cfa by the Koppen-Geiger system [40] with dry summers and foggy winters.

The aim of this study is two create two different shadow systems: one with the implementation of vegetation and the other only with the ropes. The concept is presented in Figure 1.
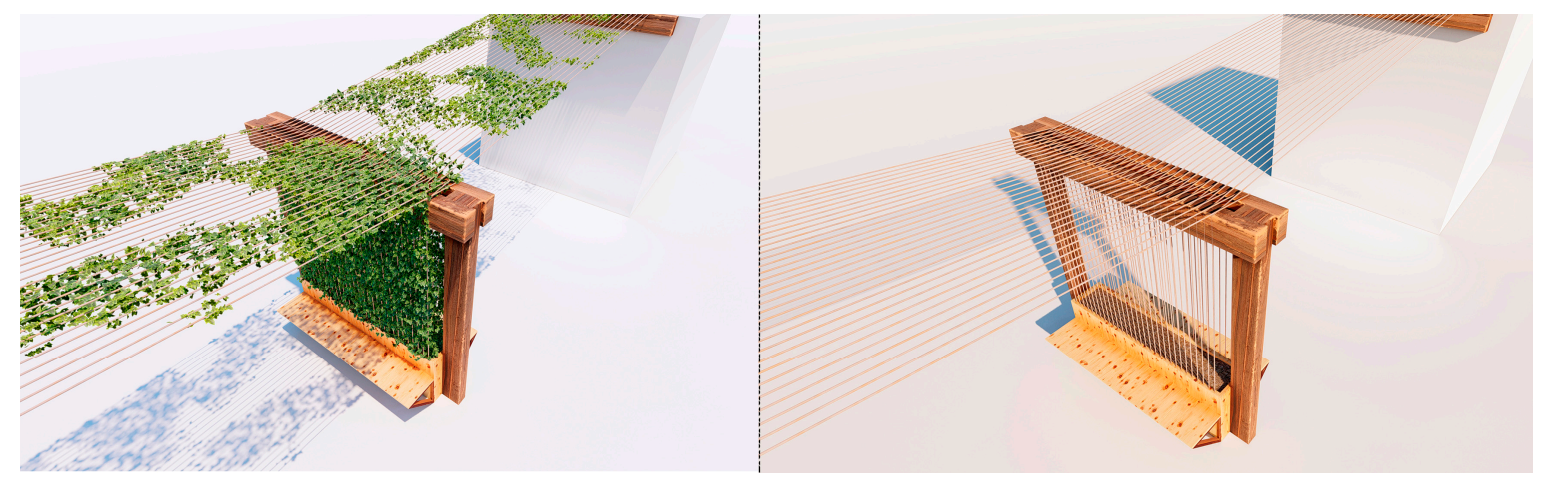

Figure 1. Concept of the pergola.

In this context, a system to create different spaces that can provide thermal comfort to outdoor users was developed. Both shading systems were composed of two interwoven systems of ropes running freely between two buildings (Figure 2). The two systems of ropes were east and west oriented and connected in the middle creating a bench where people could sit. The new space changed constantly with shadows produced by the ropes and greenery system (using deciduous plants) based on the season since the solar irradiance was different for each one. Thus, the space became an ever-changing stage responding to the movement of the visitor, the changing patterns of light through the day, and the outdoor thermal comfort depending on the season.

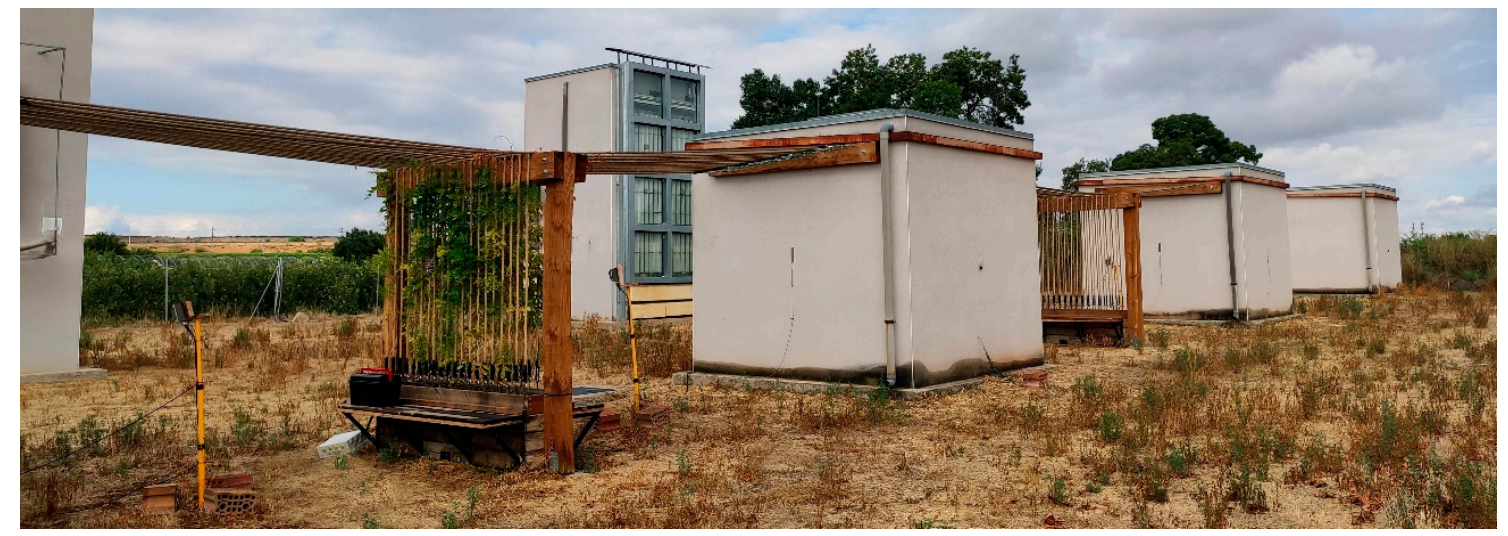

Figure 2. The two shadow systems, on the left with greenery and on the right without greenery. 
The system was realized in order to be as sustainable as possible. The materials chosen were either from recycling operations or mostly recyclable (wooden parts and ropes); the remaining metallic materials (hooks, tie rods, L-profiles) were purchased. In detail, the materials used for the prototype were the following: the seat was realized with disused pallets (once used for the transport of fruit); the structure that supports the ropes was built with wooden crossbars coming from rails, treated to allow their reuse.

As seen in Figure 3, the pergola was made up of tensed ropes fixed by means of hooks to the seat and by hooks with tie rods to the facade of the cubicle. The ropes were not fixed directly on the facade of the cubicle but were placed on a wooden crossbeam, in a diagonal way, so as to ensure the pergola a more pleasant and natural profile. The rope, with a diameter of $16 \mathrm{~mm}$, was intertwined transversally (i.e., the ropes of the east seat were tied to the west, and vice versa) in order to guarantee greater structural stability. In detail, the ropes were passed through the screw eyelets, fixed to the seat, and knotted with a heat-shrinkable sheath.

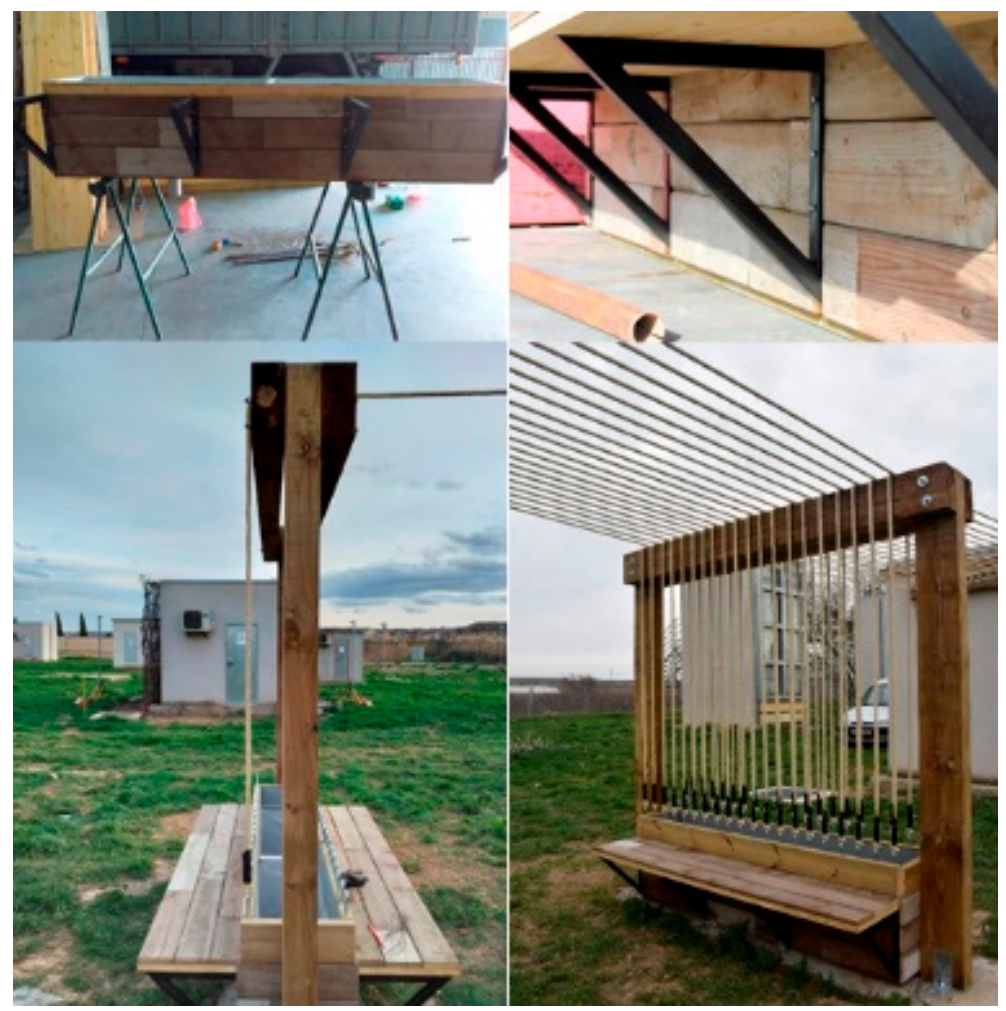

Figure 3. Construction process of the pergola.

Each structure was equipped with two seats, one to the east and the other to the west side; flower boxes were placed between the two seats. Wisteria sinensis climbing plants were placed in the box of one of the two structures and during the experiment, the growth, usefulness, and type of maintenance required were observed. The Wisteria sinensis was chosen because it is suitable for the type of Mediterranean continental climate present in the experimental area of Lleida and for its ability to develop without the support of a wall, but with the simple aid of a rope (Figure 4). Moreover, due to the dry climate in the study site, a simple irrigation system was installed and programmed to irrigate the greenery 4 times per night (9 p.m., 12 a.m., 4 a.m. and 8 a.m.) of minutes each. 


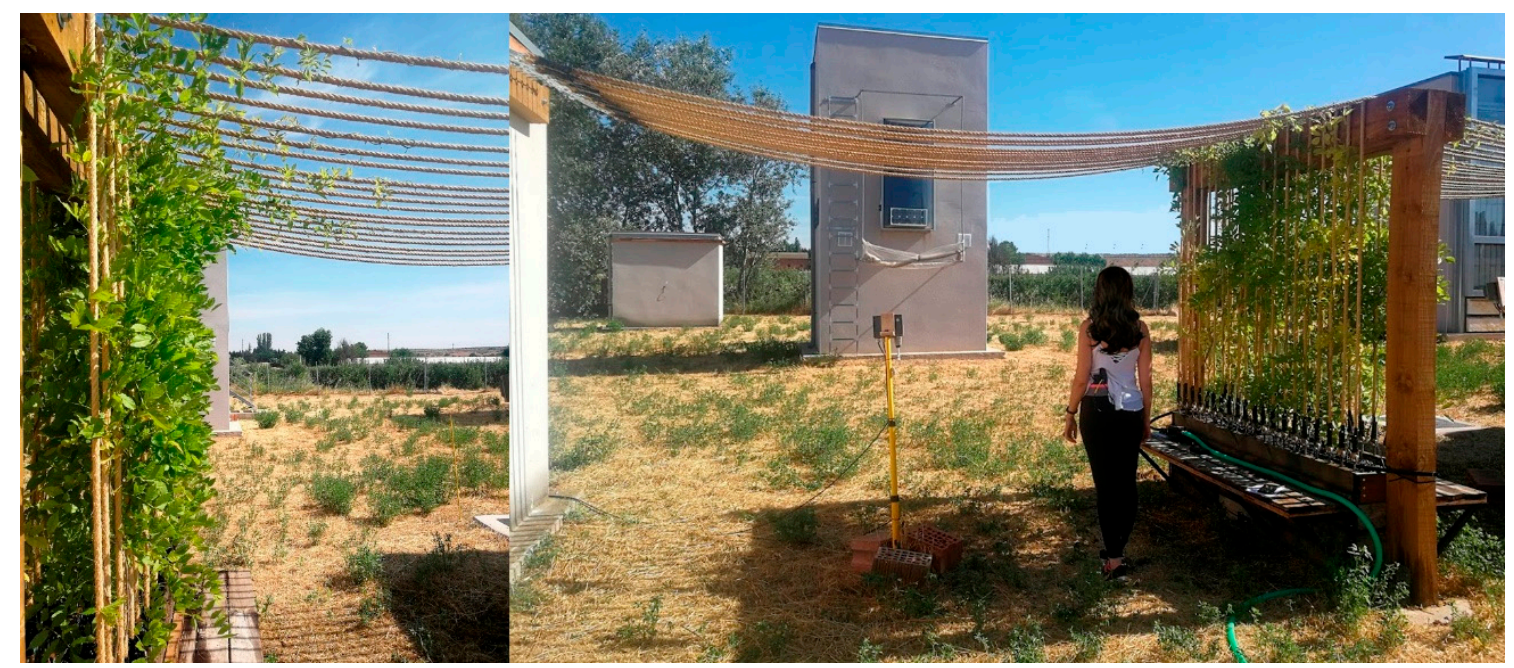

Figure 4. The Wisteria sinensis on the wall of the shadow element.

\subsection{Instrumentation}

Five sensors to measure air relative humidity $(\% \mathrm{RH})$ and temperature $\left({ }^{\circ} \mathrm{C}\right)$ were installed. Two sensors (west (A) and east (B) orientation) were installed under the greenery system, two more under the ropes system, and the last one in the area without any shadow system (Figure 5). The sensors were placed at $1.60 \mathrm{~m}$ height from the ground (human torso height for a standard man) and in the middle between the bench/pergola and the house-like cubicle, namely at a distance of $2.25 \mathrm{~m}$ from the cubicle wall. A modified tripod was used to support the sensors as seen in Figure 4.

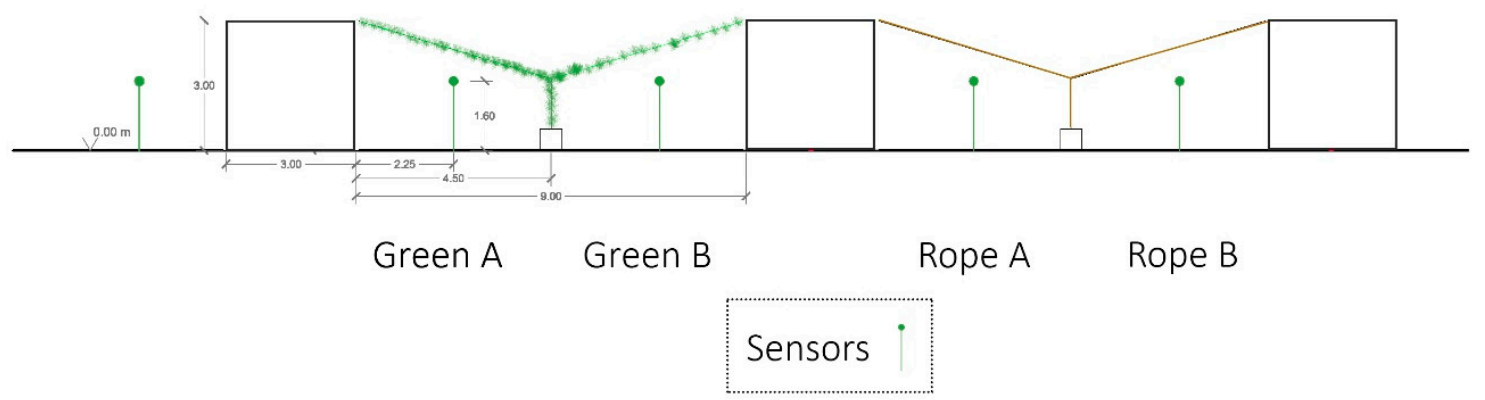

Figure 5. The experimental set-up.

The whole experimental set-up was continuously monitored to analyze the thermal performance of each tested pergola. The data was registered every $5 \mathrm{~min}$ interval. In detail, the sensor used for the both shading systems was a TESTO 6651 humidity transmitter compatible with TESTO 6601, with an accuracy of $\pm 1.7 \% \mathrm{RH}$, a range of $0-100 \% \mathrm{RH}$ and a temperature range from $-20{ }^{\circ} \mathrm{C}$ to $70{ }^{\circ} \mathrm{C}$. Measurements were made with a range of $1 \mathrm{~s}$. On the other hand, solar global radiation $\left[\mathrm{W} / \mathrm{m}^{2}\right.$ ] was taken by a weather station which includes two MIDDLETON SOLAR meters SK08 to capture horizontal and vertical global solar radiation. Both sensors can be seen in Figure 6.

In addition, thermal imaging was carried out to compare the surface temperatures of the shading systems at different times of the day. Therefore, thermal images of the inner surface of the ropes with and without greenery were taken during a representative summer day (29th June) with peak outdoor air temperature equal to $45^{\circ} \mathrm{C}$. To this aim, a FLIR Vue Pro R camera was used to gather accurate, calibrated, and non-contact temperature measurements. The thermal camera and its main technical characteristics are shown in Table 1. 


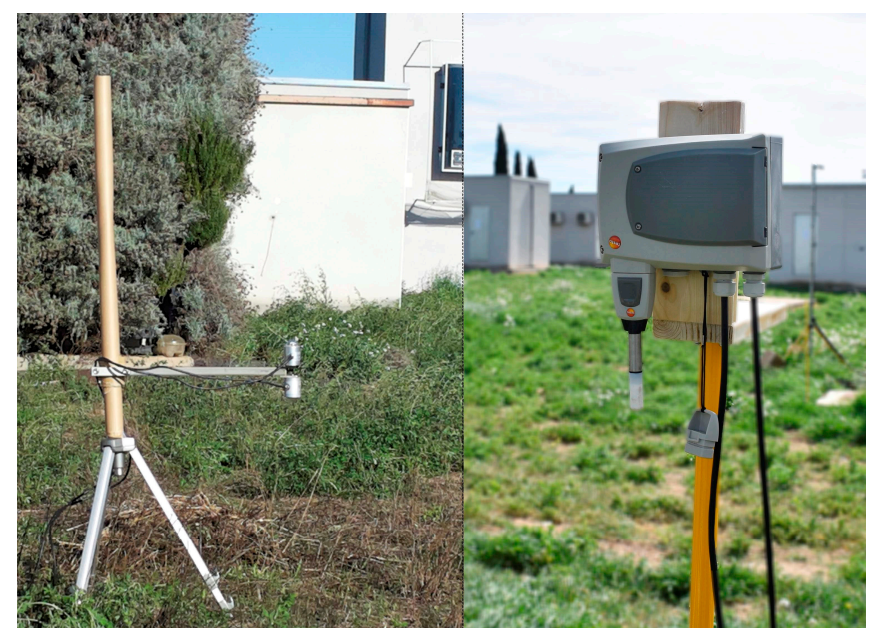

Figure 6. On the left, Middleton Solar meter. On the right, Testo 6651 for air temperature and relative humidity.

Table 1. FLIR Vue Pro R thermal camera and main technical characteristics.

\begin{tabular}{ccc} 
& \multicolumn{3}{c}{ Technical Characteristics } \\
\cline { 2 - 3 } & Thermal Imager & Uncooled VOx Microbolometer \\
\hline & $\begin{array}{c}\text { Sensor Resolution } \\
\text { Spectral Band }\end{array}$ & $336 \times 256$ \\
Operating Temperature & $7.5-13.5 \mu \mathrm{m}$ \\
Range & $-20{ }^{\circ} \mathrm{C}$ to $+50{ }^{\circ} \mathrm{C}$ \\
& Measurement Accuracy & $\pm 5{ }^{\circ} \mathrm{C}$ or $5 \%$ of reading
\end{tabular}

\subsection{Experiments}

The experimental set-up allows conducting different types of experiments. First, differences in terms of air temperatures and relative humidity between the various scenarios were assessed. The experiments were done during June and the beginning of July since this is the hottest month in Lleida, Spain (continental Mediterranean climate). Thus, 8 consecutive days from 27-06-2019 to 04-07-2019 were continuously monitored.

The second experiment consisted of comparing the surface temperatures between the ropes and the greenery at different hours of the day. These analyses were carried out during the same period as the previous one.

\section{Results and Discussion}

\subsection{Thermal Analysis}

The air temperature under the system with greenery (Green A) and the system with the ropes (Rope A) on west orientation were analyzed. To consider the most extreme conditions, the week with the highest temperatures of the whole summer 2019 was chosen as representative week, which was the one between the end of June and the beginning of July. As shown in Figure 7, all days of the week had very similar and high solar irradiance. Between these two scenarios, the highest air temperature (i.e., $45.3^{\circ} \mathrm{C}$ ) was detected under the system with the ropes on the day 29/06/2019 at 3:45 p.m. The maximum temperature reached with the greenery system was $42.9^{\circ} \mathrm{C}$ on the same day, which means a difference up to $2.5^{\circ} \mathrm{C}$ at peak temperatures for the same day with the same external conditions. Furthermore, the temperature difference during night was overwhelming with up to $3.1^{\circ} \mathrm{C}$ at 5:50 a.m. the day 30/06/2019, being the lowest temperature reached by the greenery system and the system with ropes $9.0^{\circ} \mathrm{C}$ and $12.1{ }^{\circ} \mathrm{C}$, respectively. These differences mean a reduction up to $5 \%$ and 
$25 \%$ during daytime and night-time, respectively, thanks to the implementation of greenery. This high reduction of temperatures at night might be due to the irrigation effect [41]. Other authors, indeed, have deeply studied and confirmed that the reduced temperatures on average and hot summer days are due to irrigation as well as the evapotranspiration effect [18].

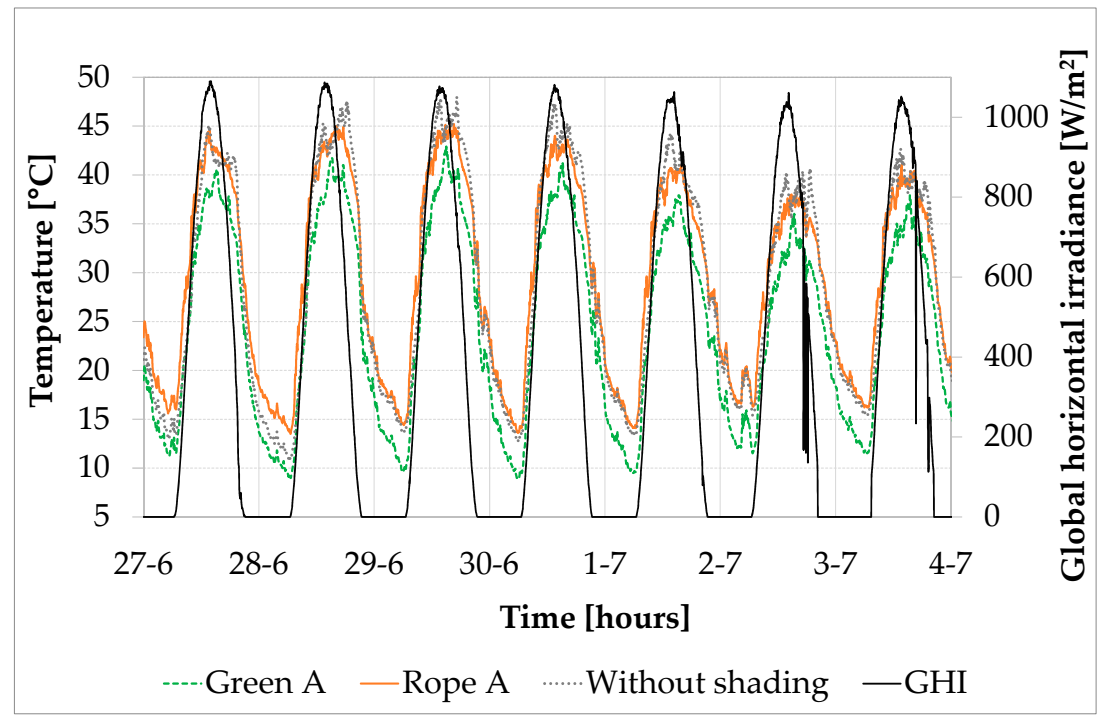

Figure 7. Air temperatures under the west oriented shading systems (Green A/Rope A).

Moreover, these results are confirmed by the thermal images of the two shading systems (Figure 8). The surface temperatures difference between the ropes and the system with greenery at the time of peak outdoor air temperature (i.e., 4:00 p.m. on the same day 29/06/2019) was up to $5.3^{\circ} \mathrm{C}$. The greenery, indeed, reached up to about $37^{\circ} \mathrm{C}$, compared to the almost $43^{\circ} \mathrm{C}$ of the ropes. Therefore, this surface temperature difference affects the air temperature under the shading system, even if the passive cooling effect is slightly dampened.

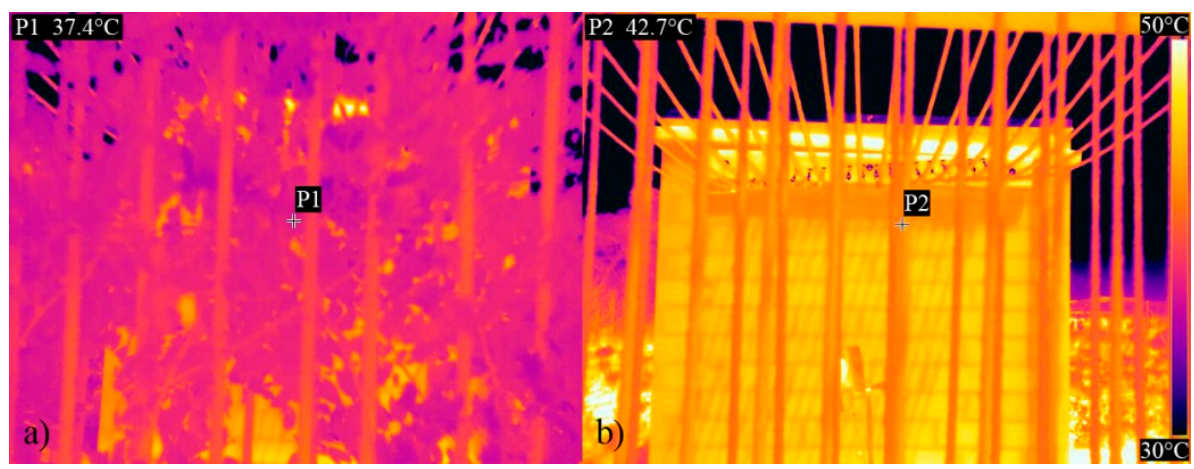

Figure 8. Thermal image of the shading systems (a) with and (b) without greenery at peak outdoor air temperature (i.e., at about 4:00 p.m).

Furthermore, when compared to the sensor without any shading system, namely "without shading", the difference was even higher. The difference between the highest air temperature with the greenery system and the maximum non-shaded temperature was $5.1{ }^{\circ} \mathrm{C}$, while the minimum was $1.9^{\circ} \mathrm{C}$. On the other hand, the system with the ropes was very similar to the one without any shading system.

Accordingly, the implementation of the greenery in outdoor surfaces has a cooling effect on the environment and hence provides more comfortable surroundings to the citizens. Since previous studies showed that cities and towns are warmer than their surrounding rural areas due to the absorption of 
solar radiation by the urban built surfaces [42], these results highlight the importance of the use of greenery on the outdoors for cooling down the cities.

On the other hand, air temperature under the east oriented pergolas (Green B / Rope B) were analyzed in Figure 9. In this case, the air temperature variation differed from the west oriented scenarios (Green A / Rope A). Again, the system with the greenery showed better results, with maximum air temperatures up to $44.9^{\circ} \mathrm{C}$, while under the system with ropes and without any shading system the temperature reached up to $48.4^{\circ} \mathrm{C}$ and $48.0^{\circ} \mathrm{C}$, respectively. Regarding the lowest air temperatures, the greenery system reached $12.1^{\circ} \mathrm{C}$ during night-time, while the system with ropes $13.9^{\circ} \mathrm{C}$. However, in this case the lowest air temperature was found for the sensor without any shading system equal to $10.9{ }^{\circ} \mathrm{C}$. It is worth noting that slightly cooler air temperatures were observed under the west oriented pergolas, which could mean that in the case study climate context shading systems are more efficient in the west orientation. Moreover, this outcome highlights that the context and orientation are very important parameters to consider when planning and designing this type of systems.

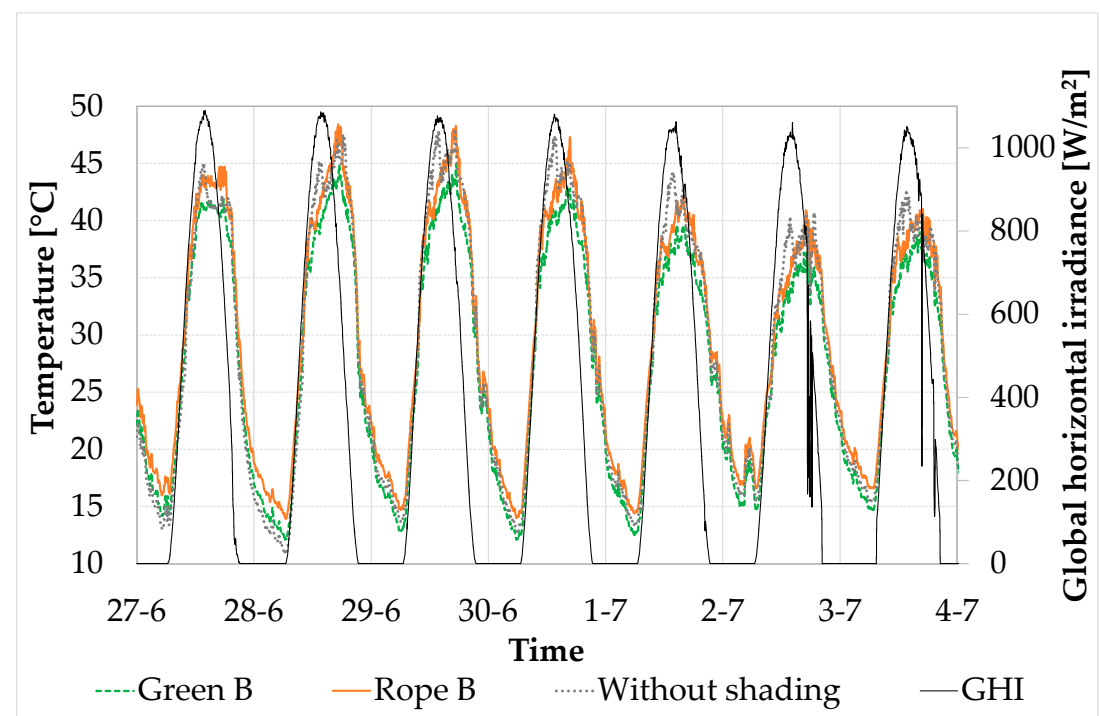

Figure 9. Air temperatures under the east oriented shading systems (Green B/Rope B).

\subsection{Hygrometric Analysis}

In addition, relative humidity (RH) was studied, since it is another important aspect for outdoor thermal comfort. Relative humidity indicates the actual amount of water vapor content (percent) in the air compared to the maximum amount that the air could hold under the same conditions. The warmer the air, the more moisture it can hold. Humidity is almost always higher in green areas than in built environments [43], since greenery systems can increase the relative humidity of the surrounding air by its wet substrate and by the transpiration of plants [44].

Figure 10 presents the comparison of the RH trend under the two shading systems for the west orientation in two consecutive days. The solid line shows the fluctuation of air temperatures while the dotted line represents the variation of relative humidity. The air under both shading systems reaches the saturation during the coolest hours. However, the RH appears always higher under the greenery up to a minimum equal to $15 \%$ in the driest sunny hours, when the $\mathrm{RH}$ under the ropes reaches a value of $12 \%$.

On the other hand, Figure 11 shows the RH under the east oriented shading systems. In this case, the data show negligible differences in terms of relative humidity with or without greenery, which confirms the previous findings on the variation of the effectiveness of the green pergola according to the orientation. 


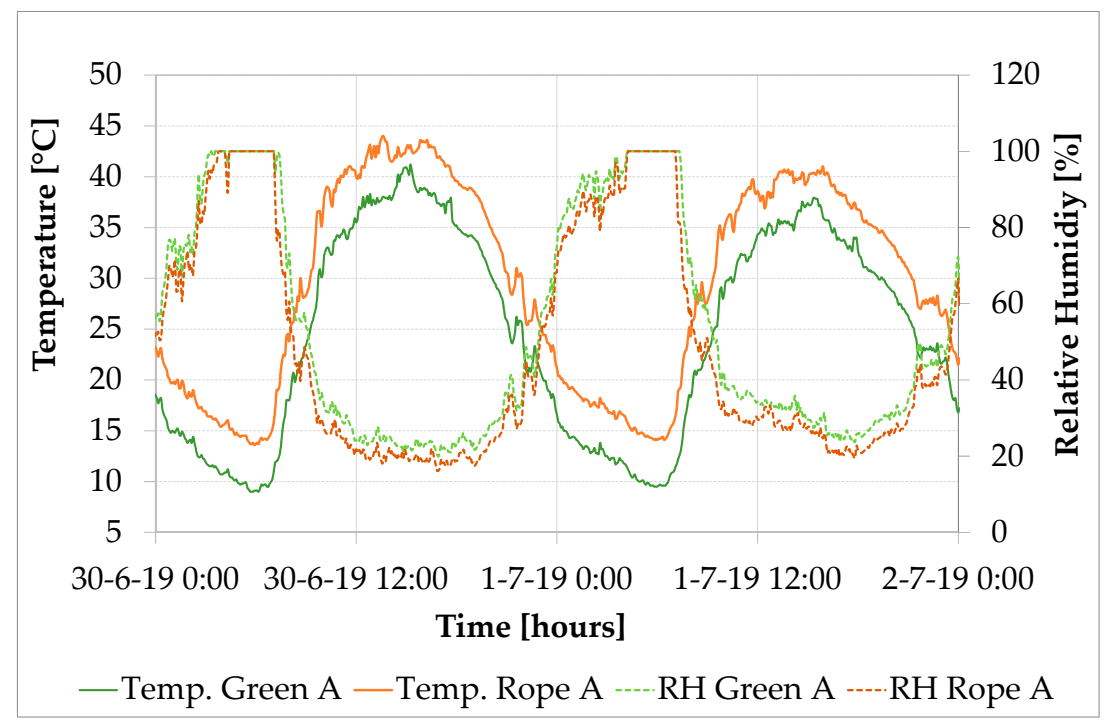

Figure 10. Relative humidity under the west oriented shading systems for two consecutive days.

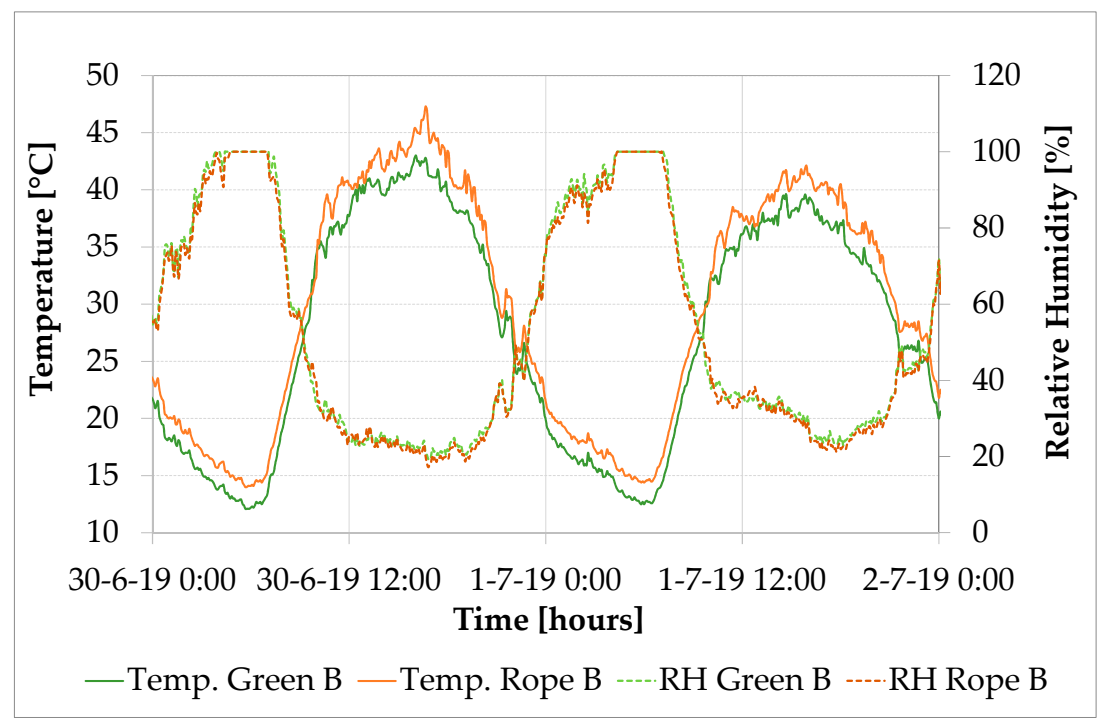

Figure 11. Relative humidity under the east oriented shading systems (Green B/Rope B).

Overall, greenery is quite effective in increasing the RH. In fact, the average relative humidity was higher under the greenery system thanks to the moisture released by vegetation into the air through the process of evapotranspiration.

These results confirm other researchers' findings that declared the cooling effect of different systems of shades, such as pergolas, trees, buildings, etc. in different regions. Watanabe et al. [45] analyzed temperature differences between sunlight, building shade, and pergola shade during summer in a humid subtropical region. The building shade and pergola shade with plants provided cooler thermal environments with important ETU (universal effective temperature) reductions of $18.4{ }^{\circ} \mathrm{C}$ and $16.2{ }^{\circ} \mathrm{C}$, respectively, compared with sunlight. In the tropical climate of Singapore, Wong and Peck [46] carried out a study to see the effect of the vegetation. From the experimental results collected, the site with higher greenery coverage showed lower temperature and higher relative humidity in comparison to the other site with lower vegetation. Colter et al. [47] studied the capacity of natural and artificial shade types to improve outdoor human comfort during normally hot summer midday. They concluded that selecting trees that mostly attenuate solar radiation is the most effective urban design strategy. 


\section{Conclusions}

Responsible actions to deploy UGI are urgently needed in this historic period impacted by increasing anthropic climate change, accelerated transformation of the urban/peri-urban landscape, and their related risks. In fact, greening cities is a concept that has gained increasing relevance in the last decades and more studies that experimentally demonstrate its effectiveness allow promotion of the implementation of greenery systems among city planning and governments providing measurable wellness benefits.

In this view, this study aimed to assess the evidence of the effectiveness of greenery as a passive cooling strategy for outdoor urban spaces. In detail, the purpose was to analyze the effect of greening a shading system on the temperature of the surrounding environment compared to the same system without greenery in a Mediterranean continental climate. On-site experiments were conducted in summer 2019.

In clear conditions, for the west oriented pergolas the maximum air temperature difference between the rope system and the greenery was found at 4:00 p.m. on 29 June 2019 during daytime with a difference of $2.5{ }^{\circ} \mathrm{C}$. At night, a $3.1{ }^{\circ} \mathrm{C}$ difference was measured on 30 June 2019, concretely at 5:50 a.m. Concretely, the maximum temperature under the system with the ropes was $45.3^{\circ} \mathrm{C}$, while at the same time the air temperature under the greenery system was $42.9^{\circ} \mathrm{C}$. With respect to the east oriented sensors, the difference was less interesting than the west oriented sensors, which could mean that, in the Mediterranean continental climate, shading systems are more efficient in the west orientation.

Regarding the air relative humidity, for the west orientation, the RH always appears higher under the greenery up to a minimum equal to $15 \%$ in the driest sunny hours, when the RH under the ropes reaches a value of $12 \%$. On the other hand, no significant differences were found for the east sensors.

These results highlight that context and orientation are very important parameters to consider when planning and designing this type of systems. Greenery shading systems can therefore be recommended to be considered as a complementary solution beside other mitigation strategies. However, note that the findings obtained in this study should be adapted for particular situations and climates. The results cannot be generalized for all climates, thus, further research in different contexts and climate regions should be analyzed.

Author Contributions: Conceptualization, M.C., A.L.P., L.F.C.; methodology, A.L.P.; validation, A.L.P., L.F.C.; formal analysis, M.C., C.P.; investigation, M.C., L.F.C.; resources, L.F.C.; data curation, L.F.C.; writing-original draft preparation, M.C.; writing-review and editing, C.P., A.L.P., L.F.C.; visualization, M.C.; supervision, L.F.C., A.L.P.; project administration, L.F.C.; funding acquisition, L.F.C., A.L.P. All authors have read and agreed to the published version of the manuscript.

Funding: This work was partially funded by the Ministerio de Ciencia, Innovación y Universidades de España (RTI2018-093849-B-C31 - MCIU/AEI/FEDER, UE). This work was partially funded by the Ministerio de Ciencia, Innovación y Universidades - Agencia Estatal de Investigación (AEI) (RED2018-102431-T). The authors from University of Perugia thank Fondazione Cassa di Risparmio di Perugia for supporting the investigation about biomaterials within the project SOS CITTÁ 2018.0499.026.

Acknowledgments: The authors would like to thank the Catalan Government for the quality accreditation given to their research group (2017 SGR 1537). GREiA is a certified agent TECNIO in the category of technology developers from the Government of Catalonia. This work is partially supported by ICREA under the ICREA Academia programme.

Conflicts of Interest: The authors declare no conflict of interest.

\section{References}

1. Vukmirovic, M.; Gavrilovic, S.; Stojanovic, D. The improvement of the comfort of public spaces as a local initiative in coping with climate change. Sustainability 2019, 11, 6546. [CrossRef]

2. Badarnah, L. Form Follows Environment: Biomimetic Approaches to Building Envelope Design for Environmental Adaptation. Buildings 2017, 7, 40. [CrossRef]

3. López, M.; Rubio, R.; Martín, S.; Croxford, B. How plants inspire façades. From plants to architecture: Biomimetic principles for the development of adaptive architectural envelopes. Renew. Sustain. Energy Rev. 2017, 67, 692-703. [CrossRef] 
4. Vincent, J.F.V.; Bogatyreva, O.A.; Bogatyrev, N.R.; Bowyer, A.; Pahl, A.K. Biomimetics: Its practice and theory. J. R. Soc. Interface 2006, 3, 471-482. [CrossRef] [PubMed]

5. Zari, M.P. Biomimetic design for climate change adaptation and mitigation. Archit. Sci. Rev. 2010, 53, 172-183. [CrossRef]

6. Scott, M.; Lennon, M.; Haase, D.; Kazmierczak, A.; Clabby, G.; Beatley, T. Nature-based solutions for the contemporary city/Re-naturing the city/Reflections on urban landscapes, ecosystems services and nature-based solutions in cities/Multifunctional green infrastructure and climate change adaptation: brownfield greening as an adaptation strategy for vulnerable communities?/Delivering green infrastructure through planning: insights from practice in Fingal, Ireland/Planning for biophilic cities: from theory to practice. Plan. Theory Pract. 2016, 17, 267-300.

7. Calfapietra, C.; Cherubini, L. Green Infrastructure: Nature-Based Solutions for sustainable and resilient cities. Urban For. Urban Green. 2019, 37, 1-2. [CrossRef]

8. Kabisch, N.; Frantzeskaki, N.; Pauleit, S.; Naumann, S.; Davis, M.; Artmann, M.; Haase, D.; Knapp, S.; Korn, H.; Stadler, J.; et al. Nature-based solutions to climate change mitigation and adaptation in urban areas and their rural surroundings. Ecol. Soc. 2016, 21, 1-11. [CrossRef]

9. Wong, N.H.; Yu, C. Study of green areas and urban heat island in a tropical city. Habitat Int. 2005, 29, 547-558. [CrossRef]

10. Bowler, D.E.; Buyung-Ali, L.; Knight, T.M.; Pullin, A.S. Urban greening to cool towns and cities: A systematic review of the empirical evidence. Landsc. Urban Plan. 2010, 97, 147-155. [CrossRef]

11. Abass, K.; Appiah, D.O.; Afriyie, K. Does green space matter? Public knowledge and attitude towards urban greenery in Ghana. Urban For. Urban Green. 2019, 46, 126462. [CrossRef]

12. Zhang, L.; Wei, D.; Hou, Y.; Du, J.; Liu, Z.; Zhang, G.; Long, S. Outdoor Thermal Comfort of Urban Park-A Case Study. Sustainability 2020, 12, 1961. [CrossRef]

13. Norton, B.A.; Coutts, A.M.; Livesley, S.J.; Harris, R.J.; Hunter, A.M.; Williams, N.S.G. Planning for cooler cities: A framework to prioritise green infrastructure to mitigate high temperatures in urban landscapes. Landsc. Urban Plan. 2015, 134, 127-138. [CrossRef]

14. Park, J.; Kim, J.; Kun, D.; Yeon, C.; Gyu, S. The influence of small green space type and structure at the street level on urban heat island mitigation. Urban For. Urban Green. 2017, 21, 203-212. [CrossRef]

15. Pugh, T.A.M.; MacKenzie, A.R.; Whyatt, J.D.; Hewitt, C.N. Effectiveness of green infrastructure for improvement of air quality in urban street canyons. Environ. Sci. Technol. 2012, 46, 7692-7699. [CrossRef] [PubMed]

16. Yu, M.V.D.C. Biotechnologies and Biomimetics for Civil Engineering; Springer International Publishing: Cham, Switzerland, 2015.

17. Acero, J.A.; Koh, E.J.Y.; Li, X.; Ruefenacht, L.A.; Pignatta, G.; Norford, L.K. Thermal impact of the orientation and height of vertical greenery on pedestrians in a tropical area. Build. Simul. 2019, 12, 973-984. [CrossRef]

18. Yok, P.; Hien, N.; Liang, C.; Kardinal, S. Transpiration and cooling potential of tropical urban trees from different native habitats. Sci. Total Environ. 2020, 705, 135764.

19. Im, J. Green streets to serve urban sustainability: Benefits and typology. Sustainability 2019, 11, 6483. [CrossRef]

20. Auer, T.; Radi, M.; Brkovi, M. Green Facades and Living Walls-A Review Establishing the Classification of Construction Types and Mapping the Benefits. Sustainability 2019, 11, 4579.

21. Coma, J.; Chàfer, M.; Pérez, G.; Cabeza, L.F. How internal heat loads of buildings affect the effectiveness of vertical greenery systems? An experimental study. Renew. Energy 2020, 151, 919-930. [CrossRef]

22. Wong, N.H.; Chen, Y.; Ong, C.L.; Sia, A. Investigation of thermal benefits of rooftop garden in the tropical environment. Build. Environ. 2003, 38, 261-270. [CrossRef]

23. Pigliautile, I.; Chàfer, M.; Pisello, A.L.; Pérez, G.; Cabeza, L.F. Inter-building assessment of urban heat island mitigation strategies: Field tests and numerical modelling in a simplified-geometry experimental set-up. Renew. Energy 2020, 147, 1663-1675. [CrossRef]

24. Shari, E.; Larbi, M.; Omrany, H.; Boland, J. Climate change adaptation and carbon emissions in green urban spaces: Case study of Adelaide. J. Clean. Prod. 2020, 254, 120035. [CrossRef]

25. Magaudda, S.; D'Ascanio, R.; Muccitelli, S.; Palazzo, A.L. 'Greening' Green Infrastructure. Good Italian Practices for Enhancing Green Infrastructure through the Common Agricultural Policy. Sustainability 2020, 12, 2301. [CrossRef]

26. Gunawardena, K.R.; Wells, M.J.; Kershaw, T. Utilising green and bluespace to mitigate urban heat island intensity. Sci. Total Environ. 2017, 584-585, 1040-1055. [CrossRef] [PubMed] 
27. Urban Green Spaces and Health; WHO Regional Office for Europe: København, Denmark, 2016.

28. Andreucci, M.B.; Russo, A.; Olszewska-Guizzo, A. Designing urban green blue infrastructure for mental health and elderly wellbeing. Sustainability 2019, 11, 6425. [CrossRef]

29. Ryan, C.O.; Browning, W.D.; Clancy, J.O.; Andrews, S.L.; Kallianpurkar, N.B. BIOPHILIC DESIGN PATTERNS Emerging Nature-Based Parameters for Health and Well-Being in the Built Environment. Int. J. Archit. Res. 2014, 8, 62-76. [CrossRef]

30. Beatley, T.; Newman, P. Biophilic cities are sustainable, resilient cities. Sustainability 2013, 5, 3328-3345. [CrossRef]

31. Reeve, A.C.; Desha, C.; Hargreaves, D.; Hargroves, K. Biophilic urbanism: Contributions to holistic urban greening for urban renewal. Smart Sustain. Built Environ. 2015, 4, 215-233. [CrossRef]

32. Xue, F.; Gou, Z.; Lau, S.S.Y.; Lau, S.K.; Chung, K.H.; Zhang, J. From biophilic design to biophilic urbanism: Stakeholders' perspectives. J. Clean. Prod. 2019, 211, 1444-1452. [CrossRef]

33. El-Baghdadi, O.; Desha, C. Conceptualising a biophilic services model for urban areas. Urban For. Urban Green. 2017, 27, 399-408. [CrossRef]

34. Yang, W.; Wong, N.H.; Jusuf, S.K. Thermal comfort in outdoor urban spaces in Singapore. Build. Environ. 2013, 59, 426-435. [CrossRef]

35. Piselli, C.; Castaldo, V.L.; Pigliautile, I.; Pisello, A.L.; Cotana, F. Outdoor comfort conditions in urban areas: On citizens' perspective about microclimate mitigation of urban transit areas. Sustain. Cities Soc. 2018, 39, 16-36. [CrossRef]

36. Morakinyo, T.E.; Lai, A.; Lau, K.K.L.; Ng, E. Thermal benefits of vertical greening in a high-density city: Case study of Hong Kong. Urban For. Urban Green. 2019, 37, 42-55. [CrossRef]

37. Tan, C.L.; Wong, N.H.; Jusuf, S.K. Effects of vertical greenery on mean radiant temperature in the tropical urban environment. Landsc. Urban Plan. 2014, 127, 52-64. [CrossRef]

38. Seçkin, N.P. Environmental control in architecture by landscape design. A/Z ITU J. Fac. Archit. 2018, 15, 197-211. [CrossRef]

39. De Gracia, A.; Navarro, L.; Coma, J.; Serrano, S.; Romaní, J.; Pérez, G.; Cabeza, L.F. Experimental set-up for testing active and passive systems for energy savings in buildings-Lessons learnt. Renew. Sustain. Energy Rev. 2018, 82, 1014-1026. [CrossRef]

40. Peel, M.C.; Finlayson, B.L.; McMahon, T.A. Updated world map of the Köppen-Geiger climate classification. Hydrol. Earth Syst. Sci. 2007, 11, 1633-1644. [CrossRef]

41. Lobell, D.B.; Bonfils, C.J.; Kueppers, L.M.; Snyder, M.A. Irrigation cooling effect on temperature and heat index extremes. Geophys. Res. Lett. 2008, 35, 1-6. [CrossRef]

42. Jusuf, S.K.; Ignatius, M.; Hien, W.N.; Akbari, H. Editorial: Urban Heat Island (UHI) and its Mitigation through Urban Planning, Design, and Landscaping. Archit. Sci. Rev. 2019, 62, 1-2. [CrossRef]

43. Galagoda, R.U.; Jayasinghe, G.Y.; Halwatura, R.U.; Rupasinghe, H.T. The impact of urban green infrastructure as a sustainable approach towards tropical micro-climatic changes and human thermal comfort. Urban For. Urban Green. 2018, 34, 1-9. [CrossRef]

44. Chen, A.; Yao, X.A.; Sun, R.; Chen, L. Effect of urban green patterns on surface urban cool islands and its seasonal variations. Urban For. Urban Green. 2014, 13, 646-654. [CrossRef]

45. Watanabe, S.; Nagano, K.; Ishii, J.; Horikoshi, T. Evaluation of outdoor thermal comfort in sunlight, building shade, and pergola shade during summer in a humid subtropical region. Build. Environ. 2014, 82, 556-565. [CrossRef]

46. Wong, N.H.; Peck, T.T. the Impact of Vegetation on the Environmental Conditions of Housing Estates in Singapore. Int. J. Archit. Sci. 2005, 6, 31-37.

47. Colter, K.R.; Middel, A.C.; Martin, C.A. Effects of natural and artificial shade on human thermal comfort in residential neighborhood parks of Phoenix, Arizona, USA. Urban For. Urban Green. 2019, 44, 126429. [CrossRef]

(C) 2020 by the authors. Licensee MDPI, Basel, Switzerland. This article is an open access article distributed under the terms and conditions of the Creative Commons Attribution (CC BY) license (http://creativecommons.org/licenses/by/4.0/). 